\title{
Om arbetslöshetens ekonomi och skam
}

\section{BENGT STARRIN, ULLA RANTAKEISU \& CURT HAGQUIST}

Varför arbetslöshet kan leda till negativa sociala och hälsomässiga konsekvenser är en fräga som intresserat forskare och samhällsdebattörer under ett par årtionden. I den följande artikeln behandlas två aspekter av denna fräga. Den ena är den ekonomiska dvs. att vi arbetar för att försörja oss, den andra den moraliska aspekten, dvs. det hedervärda $i$ att ha ett arbete och det skamliga $i$ att vara utan. I artikeln formuleras en modell-ekonomiskammodellen - för att öka vår förståelse av arbetslöshetens sociala och hälsomässiga konsekvenser.

Denna artikel handlar om två sidor av arbetslöshetsproblematiken som enligt vår mening, alltför ofta förbises i såväl den allmänna debatten som i forskningen. Den ena sidan rör den ekonomiska aspekten och den andra en specifik social aspekt som handlar om moral. Denna moraliska aspekt handlar om föreställningar om det hedervärda $\mathrm{i}$ att ha ett arbete eller det skamliga i att vara utan. Förbiseendet av

Bengt Starrin är adj professor i socialt arbete vid Institutionen för socialt arbete vid Göteborgs universitet samt vetenskaplig ledare vid Centrum för folkhälsoforskning (CFF) i Karlstad. Ulla Rantakeisu är doktorand i socialt arbete och forskningsassistent vid CFF. Curt Hagquist är fil.lic. i socialt arbete och forskare vid CFF. dessa två aspekter har - enligt vår mening - bidragit till att förståelsen av de sociala, kulturella och hälsomässiga konsekvenserna av arbetslöshet fortfarande är bristfälliga och fragmentariska.

Willis har fäst uppmärksamheten på den ekonomiska eller försörjningsmässiga aspekten och menar att en förståelse av arbetslöshetens sociala konsekvenser kräver en förståelse av vad som går förlorat under arbetslöshet nämligen lönen (Willis, 1986). Lönen är för många utan tvivel den enda belöning som de egentligen făr för sitt slit. Samtidigt är lönen det som gör andra viktiga sociala och kulturella aktiviteter möjliga i livet. 
Ekonomiska och andra materiella resurser fyller ett antal viktiga funktioner. Ekonomiska resurser bidrar till att stabilisera och vidmakthålla en etablerad livsstil. De ger dessutom möjligheter till att vidmakthålla och utvidga sociala relationer eftersom pengar oftast är -ett villkor för deltagande i sociala aktiviteter. Slutligen kan ekonomiska resurser ge en känsla av att ha kontroll och makt över situationen. Pengar ökar således oberoendet och därmed egenmakten (Underlid 1992).

Den andra av arbetslöshetens förbisedda aspekter rör den moraliska sidan. Förutom att lönearbete ger lön kan lönearbete ge en moralisk intäkt. Att själv tjäna ihop till sitt eget levebröd uppfattas som hedervärt. Att leva på arbetslöshetsunderstöd eller socialbidrag kan vara något som människor nedvärderar och som känns skamligt. Pengar frăn t.ex. socialförsäkringssystemet tycks inte ha samma höga moraliska värde som pengar man själv intjänat (Allatt \& Yeandle 1992).

Med framväxten av 1800-talets borgarklass och kapitalismens framväxt knyts framförallt mannens heder allt starkare till ekonomisk framgång. Självkontroll, självdisciplin och viljestyrka blev ledstjärnor för den framväxande borgarklassen. Betoningen av den mänskliga karaktären och mänskliga egenskaper som målmedvetenhet, prestationsförmåga och viljestyrka kom att bli viktiga ideologiska ingredienser för denna klass och kom även att bilda grunden för en alltmer framväxande individualism. Dessa värderingar blev även centrala $\mathrm{i}$ den arbetsetik som växer fram och successivt får en allt mer dominerande ställning. Under 1800-talet blev således självkontroll en ledstjärna för den framväxande borgarklassen. Hedervärd var den som lyckades i affärer. Att misslyckas i affärsvärlden var skamligt. Självmord blev för somliga det mest dramatiska sättet att rädda både sin och familjens heder.

Med arbetarrörelsens framväxt skapas också nya hedersbegrepp bl.a. kring arbete. Arbetaren vill nu vinna respektabilitet i samhällets övriga skikt och inför sig själv (Helldén 1994). Att arbeta, vara yrkeskunnig, göra ett bra jobb och göra rätt för sig blir någonting hedervärt som arbetaren kan känna stolthet inför. Arbete knyts därmed också till självkänslan. Den hedervärde arbetaren blir delvis liktydigt med den skötsamme arbetaren. Skötsamhetsidealet omfattar såväl själva arbetet som fritiden. En respektabel arbetare uppträder värdigt och humant även under fritiden (Ambjörnsson 1988).

Vi kan alltså betrakta den ekonomiska förlusten som inträder under arbetslöshet och de moralbegrepp som finns kring arbete som två aspekter som bär upp lönearbetet som dominerande arbetsform. Varje dominerande arbetsform har - historiskt sett - sin egen dominerande disciplineringsstrategi. Slaveriet upprätthölls av den vinande piskan och slaven var bunden med kedjor. Feodalismen upprätthölls genom legostadgar - lönearbetet av arbetslösheten. Arbetslöshet eller hot om arbetslöshet kan således ses som en modern ersättning för den vinande piskan under slaveriet syftande till att förmå människor att utföra mer eller mindre omänskliga jobb för att kunna överleva. Arbetslöshet är ett oerhört viktigt disciplineringsmedel för kapitalägare och arbetsgivare. Som discip- 


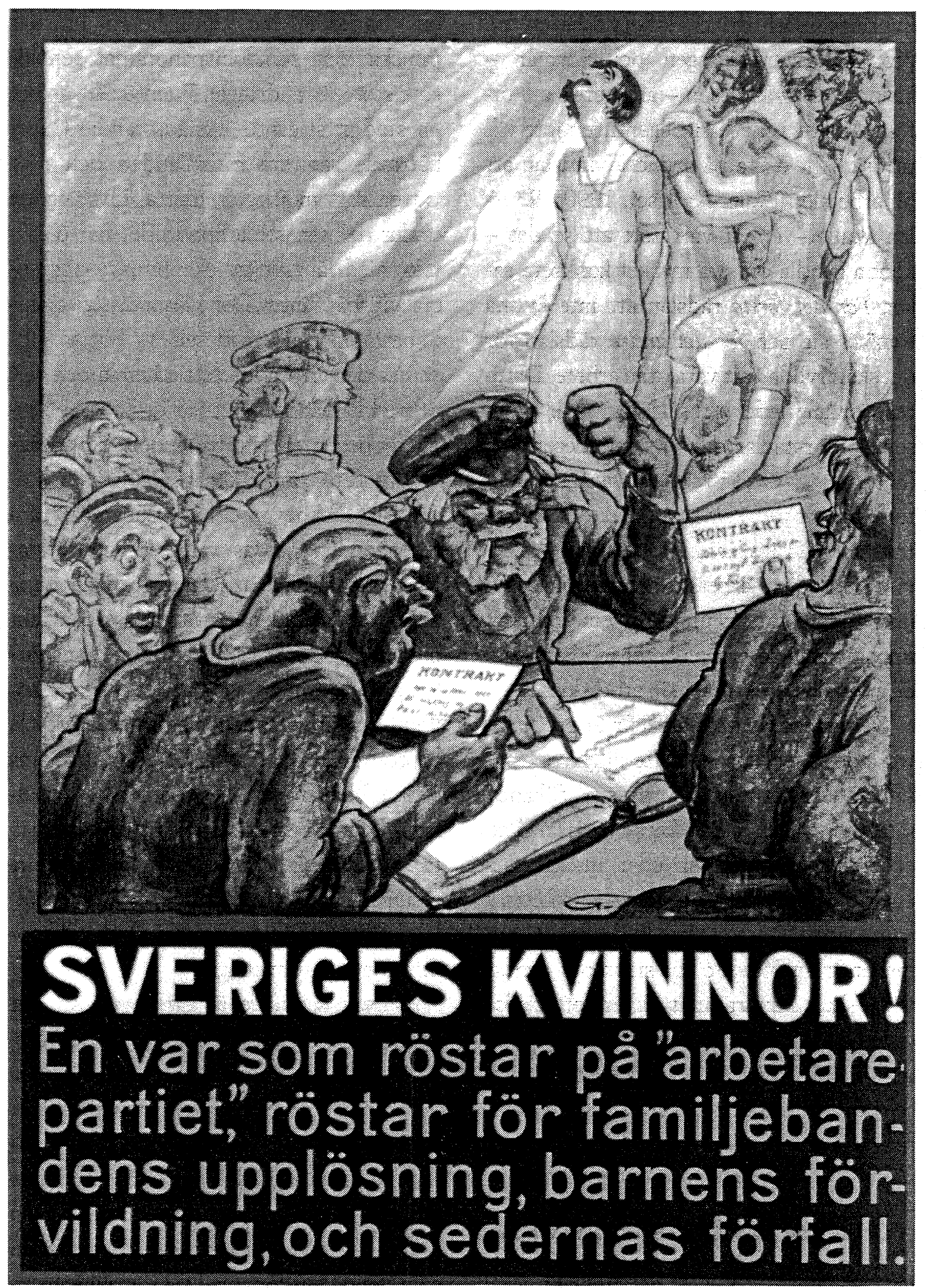

Starrin, Rantakeisu \& Hagquist - Om arbetslöshetens ekonomi och skam 
lineringsmedel driver arbetslösheten på produktionsutvecklingen och förmår hävdar Adler-Karlsson - arbetaren att utföra arbeten som denne egentligen inte vill utföra. Allt detta på grund av rädslan att bli arbetslös (Adler-Karlsson 1990). Rädslan skulle - enligt vårt sätt att se det kunna handla om två mycket konkreta saker. För det första rädslan att inte kunna försörja sig och för det andra rädslan för det skamfyllda i att vara utan arbete. Detta resonemang leder också fram till hypotesen att förståelsen av arbetslöshetens effekter kräver en förståelse av såväl den materiella aspekten som den kulturella aspekten av socialt liv. Konkret innebär detta att vi bör studera arbetslöshetens effekter i ljuset av de försörjningsproblem som kan uppstå samt de erfarenheter av skam som de arbetslösa gör under sin arbetslöshet.

Syftet med den här artikeln är att penetrera dessa två aspekter lite djupare. Uppsatsen kommer att disponeras på följande sätt. Först behandlas kopplingen mellan ekonomisk påfrestning eller utsatthet å ena sidan och ohälsa och sociala problem å andra sidan. Därefter behandlas relationen mellan arbetslöshet å ena sidan och aspekter av skam å andra sidan. Efter detta redovisar vi ett försök att förstå arbetslöshetens sociala och hälsomässiga konsekvenser som en funktion av ekonomisk påfrestning och skam.

\section{Den ekonomiska aspekten}

Erfarenheterna visar att det finns en nära koppling mellan ett lands sociala och ekonomiska nivå och hälsan hos befolkningen (McKeown 1975). Sedan industrialisering- ens barndom har dödligheten kraftigt minskat och sjukdomspanoramat genomgått stora förändringar. Framförallt är det en stadigt stigande levnadsstandard, förbättrade sanitära förhållanden och rent vatten som möjliggjort detta. Livslängden under det senaste århundradet har ökat i takt med långsiktiga ekonomiska och sociala förbättringar. Den hälsomässiga ojämlikhet som rådde vid seklets början tillskrevs den utbredda fattigdomen och det utbredda eländet. Det var de fattigas livsvillkor och levnadsförhållanden som ansågs utgöra den primära orsaken. Dåliga bostäder, otillräckligt med mat, dåliga sanitära förhållanden ansågs vara viktiga förklaringar. I takt med att levnadsförhållandena på en rad områden förbättrades och i takt med byggandet av välfärdsstaten fanns förhoppningar om att sambandet mellan ekonomiska förhållanden, ohälsa och sociala problem skulle kunna brytas (Williams 1990). Tanken var att ekonomiska förhållanden hade betydelse upp till en viss nivå för att förklara skillnaderna mellan olika gruppers hälsomässiga och sociala förhảllanden. Ovanför denna nivå skulle ekonomins betydelse avklinga.

Dagens samhälle är ett annat än det samhälle som våra förfäder levde och verkade $\mathrm{i}$ under indistrialiseringens tidiga barndom. Mycket har hänt och frägan är vilken betydelse som ekonomin har i människans sociala liv idag? Frågan har kommit att bli allt mer uppmärksammad. Den djupa lägkonjunkturen och de problem som denna har fört med sig för olika grupper av människor har bidragit till detta ökade intresse. Inte minst spelar de höga arbetslöshetssiffrorna en väsentlig roll. 
Hur ekonomiska konjunkturer inverkar på utbredningen och förekomsten av sociala problem och ohälsa intresserade en av sociologins klassiker nämligen Emile Durkheim (Durkheim 1968). Det är en fråga som för 15 år sedan återigen kom att få en stor uppmärksamhet i samband med den amerikanske sociologen Harvey Brenners tidsserieanalyser av sambandet mellan ekonomi och ohälsa (Brenner 1971, 1979, 1983, 1987).

Men det är inte de makroorienterade utan de mikroorienterade studierna som står i fokus för vårt intresse i denna uppsats. En stor del av den forskning som intresserat sig för frågan om betydelsen av ekonomiska förhållanden för förståelse av uppkomsten av sociala problem och ohälsa tar sin utgångspunkt i forskningen om vad som brukar benämnas ekonomisk deprivation. Det är vanligt att dessa studier visar på en direkt koppling mellan låg ekonomisk status eller fattigdom och indikatorer på ohälsa såsom försämrad mental hälsa, försämrad somatisk hälsa och liknande. Studier av lokalsamhällen uppvisar ett konsistent förhållande mellan inkomst och graden av rapporterad livstillfresställelse och trivsel - ju sämre ekonomi man har desto mer otillfredsställd är man med sitt liv (Campbell 1981). Sambandet gäller också på aggregatnivå, dvs ju större andel låginkomsttagare i området desto större är utbredningen av olika psykiska och fysiska besvär. Jämför man ytterligheterna i den sociala klassgradienten kan förekomsten av mer allvarliga psykologiska besvär vara fyra gånger så hög i den lägsta sociala klassen som i den högsta (Link \& Dohrenwend 1980).
Sammanställningar av data från Sverige visar att den sociala klassgradienten förefaller vara påfallande beständig över olika sociala förhållanden. Används den numera gängse indelningen »ej facklärda arbetare«,»facklärda arbetare«,»tjänstemän på lägre nivåu,ntjänstemän på mellan nivåu och "tjänstemän på högre nivåı frapperas man av den uniformitet som uttrycks i data med avseende pá den socioekonomiska gradienten. Oavsett vad man väljer att studera för typ av levnadsförhållanden - fritid, sociala relationer, trygghet och säkerhet, arbetsmiljö, ohälsa, hälsorelaterad livsstil - är det vanligen så att en större andel av de ej facklärda arbetarna har det sämre ställt än facklärda arbetare som i sin tur har det sämre ställt än lägre tjänstemän, som i sin tur har det sämre ställt än tjänstemän på mellannivå osv (Starrin \& Svensson 1992).

\section{Oroför privatekonomin bland arbetslösa}

Privatekonomins betydelse för att förstå arbetslöshet har sannolikt ökat i takt med att arbetslöshetsersättningen försämrats och arbetslöshetsperioderna blivit längre. I några nyligen genomförda undersökningar ställdes frågan "Vad är det som oroar Dig mest inför framtiden?" (Hagquist, Carlsson, Rantakeisu \& Starrin 1996). Som framgår av tabell 1 är det watt få ekonomin att gå ihop" som kommer i förgrunden för såväl unga arbetslösa män och kvinnor som uppsagda järnverksarbetare.

\section{Att levapå lån och sparade medel}

Det är svårt att egentligen få ett bra mått på arbetslösa individers levnadsförhållan- 
Tabell 1

Oro inför framtiden (Vad är det som oroar Dig mest inför framtiden?)

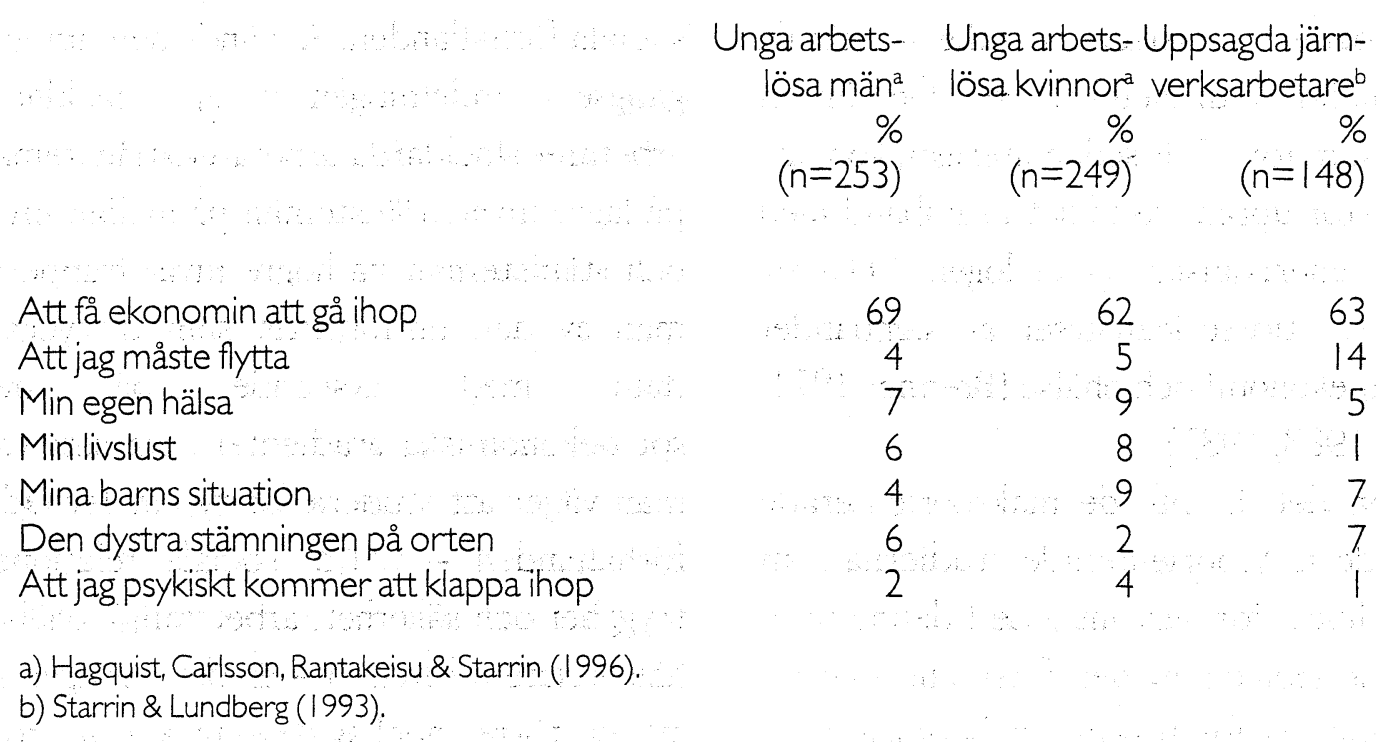

den. Arbetslösheten innebär för det absoluta flertalet en inkomstförlust som kräver att man anpassar sig till en tillvaro med mindre pengar. Det är inte alls ovanligt att man som arbetslös har svårigheter att klara av sin ekonomi. Alla uppbär inte ersättning från a-kassa och utgiftssidan kan variera. Det förekommer att man tvingas låna pengar, sälja och pantsätta ägodelar. Det förekommer även att man stöttas ekonomiskt av anhöriga. I en norsk longitudinell undersökning fann man att det var vanligt att arbetslösa ungdomar fick ekonomiskt stöd från flera håll under en arbetslöshetsperiod (Rosvold \& Hammer 1991). Det var t.ex. vanligt med ekonomiskt stöd också från föräldrar eller sambo/äkta hälft utöver arbetslöshetsersättning.

I en nyligen genomförd undersökning bland unga arbetslösa i Värmland framgår att drygt hälften av de arbetslösa tvingats att använda sparade medel under arbetslösheten (tabell 2). Av undersökningen framgår vidare att ca var femte ung man och drygt var fjärde ung kvinna vänt sig till socialkontoret för att få ekonomisk hjälp. Vanligt är också att de unga arbetslösa fått hjälp från föräldrar släkt eller vänner för att klara av utgifterna. Var femte ung man har sålt ägodelar för att klara utgifterna.

En studie från England tyder möjligen på att det finns vissa bestämda könsbestämda sätt att hantera ekonomin på under arbetslöshet (Warr, Banks \& Ullah 1985). Den indikerar att unga arbetslösa män i större utsträckning hade problem med att få ekonomin att gå ihop. Det är dock svårt att uttala sig om hur utbrett det empiriska stödet är för dessa skillnader. I undersökningen från Värmland är sådana skillnader svåra att skönja (se tabell 3).

En något större andel av männen har svårt att betala räkningarna i tid. Samtidigt är det en större andel kvinnor som ofta måste avstå från saker och ting på grund av att de inte har råd och en större andel som 


\section{Tabell 2}

Andelen unga arbetslösa som sedan de blev arbetslösa använt sparade medel, tvingats ta lån, uppsökt socialkontoret, fått pengar av anhöriga, tvingats sälja ägodelar samt tvingats pantsätta ägodelar.

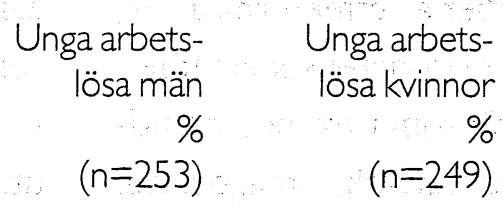

Har sedan man blev

arbetslös...

tvingats använda sparade medel

tvingats ta lån för att klara utgifterna

uppsökt socialkontoret för att få socialhjälp

fått pengar från föräldrar, släkt eller vänner

för att klara av utgifterna

47

tvingats sälja ägodelar för att klara av

utgifterna

19

tvingats pantsätta ägodelar för att klara

av utgifterna

Källa: Rantakeisu, Starrin \& Hagquist (1995b).

\section{Tabell 3}

Erfarenheter av skilda ekonomiska problem bland unga arbetslösa män och kvinnor (andelen som svarat "stämmer helt och hållet« eller "stämmer ganska bra" på varje påståenden).

$\begin{array}{rr}\begin{array}{r}\text { Unga arbets- } \\ \text { lösa män }\end{array} & \begin{array}{r}\text { Unga arbets- } \\ \%\end{array} \\ \text { lösa kvinnor } \\ \%=253 & n=249\end{array}$

Svårt att betala räkningarna i tid

24

Måste ofta avstå från saker och ting: på grund av otillräckligt med pengar

Kan ofta inte hänga med kompisar på grund av att man inte har råd

Källa: Hagquist, Carlsson, Rantakeisu \& Starrin (1996). 
ofta inte kan hänga med kompisar på grund av att man inte har råd.

\section{Ekonomisk påfrestning och ohälsa}

Vanligtvis visar studier av effekterna av arbetslöshet att i arbetslöshetens spår följer olika former av besvär som t.ex. nedstämdhet, ensamhet, huvudvärk, magbesvär, sömnbesvär. Studier tyder också på att graden av ekonomisk påfrestning eller graden av ekonomisk stress har betydelse för hur allvarliga de ovan nämnda effekterna blir (Viinamäki, Koskela, Niskanen \& Arnkill 1993, Hagquist, Starrin \& Carlsson 1993, Starrin \& Lundberg 1993, Hagquist \& Starrin 1994, Mohr \& Frese 1978).

De arbetslösas ekonomiska situation och förändringar i denna tycks således vara en viktig faktor att ta hänsyn till vid undersökningar om arbetslöshetens konsekvenser. Den ekonomiska aspekten av arbetslöshet har dock inte förrän på senare tid kommit att uppfattas som problematisk. I Carles svenska undersökning av arbetslösa ungdomar, som genomfördes för nästan tio år sedan, 1984-86, drog han slutsatsen att för ungdomarna, även om de förstod att de var arbetslösa, så innebar arbetslösheten för dem ett slags skimmer av overklighet p.g.a. välfärdsstatens trygghetssystem (Carle 1992). Eller som han benämner det; de levde med en orealistisk realitet.

Man kan förvänta sig att ju svårare den ekonomiska situationen är under arbetslöshet desto allvarligare blir de sociala och hälsomässiga följderna. I tabell 4 jämförs tre olika grupper. En grupp är ekonomiskt rådsökande. Den gruppen består i huvud- sak av personer med stora privatekonomiska bekymmer - en sjättedel redovisar ett underskott på 4000 kr varje månad. Majoriteten är endera öppet arbetslösa eller i någon form av arbetsmarknadspolitisk åtgärd. En annan grupp är uppsagda järnverksarbetare. Denna grupp har indelats $i$ två undergrupper - en undergrupp som är utsatt för högre grad av ekonomisk stress och en undergrupp som är utsatt för lägre grad av ekonomisk stress. En tredje grupp utgörs av unga arbetslösa män och kvinnor. Dessa är indelade i två grupper; de som har högre grad av ekonomisk påfrestning och de som har lägre grad av ekonomisk påfrestning.

Av tabell 4 framgår vidare att ju högre den ekonomiska påfrestning är desto större är utbredning av olika typer av besvär. Utbredningen av allvarliga psykosomatiska besvär bland unga arbetslösa män som är utsatta för högre grad av ekonomisk utsatthet är mer än dubbelt så stor än bland dem som är utsatta för lägre grad av ekonomisk påfrestning. Utbredningen av maktlöshet bland unga arbetslösa kvinnor som är utsatta för högre grad av ekonomisk påfrestning är mer än tre gånger vanligare än bland unga arbetslösa kvinnor som enbart är utsatta för lägre grad av ekonomisk påfrestning.

I tabell 5 jämförs den ekonomiskt rådsökande gruppen återigen med gruppen uppsagda järnverksarbetare och unga arbetslösa män och kvinnor. Till rådsökande gruppen ställdes frågor om den ekonomiska situation man hamnat i medfört konsekvenser i olika avseenden. Till uppsagda järnverksarbetare ställdes frågor om uppsägningen medfört konsekvenser i 


\section{Tabell 4}

Utbredningen av psykosomatiska och andra besvär bland tre grupper: ekonomiskt rådsökande, uppsagda järnverksarbetare och unga arbetslösa män och kvinnor.

$\begin{array}{llll}\begin{array}{l}\text { Ekonomiskt } \\ \text { rådsökandec }\end{array} & \begin{array}{l}\text { Uppsagda } \\ \text { järnverksarbetare }\end{array} \\ \text { Män } & \mathrm{kv} & \begin{array}{l}\text { Högre } \\ \text { gradav } \\ \text { ekono- }\end{array} & \begin{array}{l}\text { Lägre } \\ \text { grad av } \\ \text { ekono- }\end{array} \\ & & \text { misk } & \text { misk } \\ & & \text { stress } & \text { stress } \\ n=42 & n=58 & n=62 & n=43 \\ \% & \% & \% & \%\end{array}$

$\begin{array}{llll}\text { Unga arbetslösae } & \\ \text { Män } & & \text { Kvinnor } \\ \text { Högre } & \text { Lägre } & \text { Högre } & \text { lägre } \\ \text { grad av } & \text { grad av } & \text { gradav } & \text { grad av } \\ \text { ekono- } & \text { ekono- } & \text { ekono- } & \text { ekono- } \\ \text { misk } & \text { misk } & \text { misk } & \text { misk } \\ \text { påfrest- } & \text { påfrest- } & \text { påfrest- } & \text { påfrest- } \\ \text { ning } & \text { ning } & \text { ning } & \text { ning } \\ n=100 & n=153 & n=87 & n=162 \\ \% & \% & \% & \%\end{array}$

Psykosomtiska

besvära

Allvarliga

psykosomatiska

besvär

44

18

2

12

$5 *$

20

$10^{*}$

Andra besvär ${ }^{b}$

Maktlöshet

Nedstämdhet

Nervositet eller oro

$\begin{array}{ll}39 & 46 \\ 52 & 60 \\ 56 & 66\end{array}$

$46 \quad 31$

31

$\begin{array}{ll}31 & 7 \\ & \end{array}$

$\begin{array}{ll}66 & 52 \quad 9\end{array}$

$\begin{array}{ll}7 & 24 \\ 2 & 27\end{array}$

$\begin{array}{ll}7 * * * & 33 \\ 13 * * & 38 \\ 11 * * & 28\end{array}$

$10 * * *$

Signifikansnivå $* * * *=p<0.001, * * *=p<0.01, *=p<0.05$

a)Med allvarliga psykosomatiska besvär avses att man i stort sett dagligen besväras av endera magont/magbesvär, huvudvärk eller sömnbesvär.

b) Här avses att man besväras i stort sett dagligen eller några gånger per vecka.

c) Starrin, Beckman, Hagquist \& Rantakeisu (1995).

d) Indikator på graden av ekonomisk stress var följande fråga »H Hur ofta grubblar Du över hur det skall gå med Din ekonomi de närmaste åren? « Frågan hade fyra svarsalternativ: I stort sett varje dag, några gånger per vecka, högst en gång per vecka, mer sällan. Svarsalternativen delades in i tre grupper: De som angav 》l stort sett varje dag« betraktades som varande utsatta för högre grad av ekonomisk stress. De som angav något av alternativet »Några gånger per vecka« betraktades som varande utsatta för medelhög grad av ekonomisk stress och slutligen de som angav »Högst en gång i veckan« eller »Mer sällan« betraktades i undersökningen som varande utsatta för en lägre grad av ekonomisk stress. Se Starrin \& Lundberg (1993). I denna artikel redovisas de som var utsatta för högre respektive lägre grad av ekonomisk stress.

e) Index »Grad av ekonomisk påfrestning« har bildats utifrån följande variabler; »Har Du sedan Du blev arbetslös tvingats använda sparade medel?«,»Har Du sedan Du blev arbetslös tvingats ta lån för att klara av Dina utgifter?《,»»Har Du sedan Du blev arbetslös uppsökt socialkontoret för att få socialhjälp?«,» Har Du sedan Du blev arbetslös tvingats att sälja ägodelar för att klara av Dina utgifter?«,»H Har Du sedan Du blev arbetslös tvingats att pantsätta ägodelar för att klara av Dina utgifter?«,»Hur mycket pengar har Du kvar att använda varje månad till mat, nöjen, kläder, bil osv. efter det att de löpande räkningarna är betalda (med löpande räkningar avses bostadskostnader, hyra, el, värme, ränta och amorteringar på skulder, dagisavgift och liknande). Försök att uppskatta så noggrant som möjligt. Svarsalternativen på »Har Du... » frågorna var ja ( kodades som en etta) och nej (kodades som en tvåa). Ekonomifrågan om hur mycket pengar man har kvar att använda varje månad var en öppen fråga som i efterhand klasssificerades i två grupper; 1000 kr eller mindre (kodades som en etta) och mer än 1000 kr (kodades som en tvåa). Den vars svar kodades som en etta och som svarat så på två eller flera av frågorna kategoriserades som »högre grad av ekonomisk påfrestning«,den som har svarat ja på I eller ingen av dessa frågor kategoriserades som »lägre grad av ekonomisk påfrestning«. Se Rantakeisu, Starrrin \& Hagquist (1995b).

Starrin, Rantakeisu \& Hagquist - Om arbetslöshetens ekonomi och skam 
olika avseenden och till arbetslösa ungdomar ställdes frågor om arbetslösheten medfört konsekvenser i olika avseenden. $\mathrm{Vi}$ kan därför jämföra de här grupperna med avseende på självupplevda konsekvenser av ekonomiska påfrestningar, uppsägningar och arbetslöshet.

Som framgår av tabell 5 förefaller negativa konsekvenser som en följd av ekonomiska svårigheter vara betydligt mer utbredda än negativa konsekvenser som en följd av uppsägningar och arbetslöshet. Försämrad hälsa, ökad konsumtion av alkohol och lugnande medel till följd av ekonomiska svårigheter är t.ex. mycket vanligare än motsvarande försämring utan åtföljande ekonomiska svårigheter. Men det är viktigt att understryka att den här undersökta gruppens ekonomiska svårigheter inte kan ses isolerat från det faktum att merparten befinner sig utanför den ordinarie arbetsmarknaden.

Försämringar till följd av arbetslöshet hos unga arbetslösa män och kvinnor drabbar framförallt de som är utsatta för högre grad av ekonomisk påfrestning. Allvarlig psykosomatisk försämring är drygt tre gånger vanligare bland unga män som är utsatta för högre grad av ekonomisk påfrestning än bland unga män som är utsatta för lägre grad av ekonomisk påfrestning. Förändringar i hälsorelaterad livsstil som t.ex. ökad konsumtion av alkohol, ökad rökkonsumtion och minskad motion tenderar vara vanligare bland dem som är utsatta för högre grad av ekonomisk påfrestning. Minskade kontakter med grannar, släkt och vänner samt kompisar är vanligare bland dem som är utsatta för högre grad av ekonomisk påfrestning.
Det förefaller således som om vi får stöd för vår tes att ju svårare den ekonomiska situationen är desto allvarligare blir följderna hälsomässigt och socialt.

\section{Nägra fallbeskrivningar av ekonomisk päfrestning}

För att i någon mån ge en mer autentisk beskrivning av vad som döljer sig bakom de redovisade sifforna skall vi här skildra två autentiska fall (fallbeskrivningarna är hämtade ur Starrin, Beckman, Hagquist \& Rantakeisu, 1995).

\section{Fallbeskrivning Ewa}

Ewa är under 30 år. Hon är ensamstående och skild sedan ett par år. Hon har två barn. Båda barnen går i skolan på dagarna. Ewa har varit arbetslös i snart ett år. Hon stämplar på halvtid - eftersom hon tidigare haft halvtidsjobb. Hon får ut $5.000 \mathrm{kr}$ i månaden. Dessutom har hon barnbidrag och bidragsförskott för barnen. Ewa har haft ekonomiska problem under ett par år. Problemen har trappats upp och blivit allt svårare. Hon bor i ett äldre litet hus som är mycket svårsålt. Huset är till försäljning sedan ett och ett halvt år tillbaka. Intervjun med Ewa äger rum i Ewas hem. Den av oss som intervjuar blir inviterad till köket. Det är välstädat, rent och snyggt - men ingen lyx.

Ewas ekonomiska situation är mycket svår. Barnens väl och ve betyder allt för henne. Hon kan inte betala alla de räkningar som kommer varje månad. Det är alltid någon räkning som hon måste låta ligga för det finns ingenting annat att göra. Banken vill inte ge henne något anstånd för de menar att hennes ekonomi inte kommer 


\section{Tabell 5}

Förändringar i hälsa/välbefinnande, psykosomatiska besvär, sociala relationer, levnadsvanor, aktiviteter inom tre grupper.

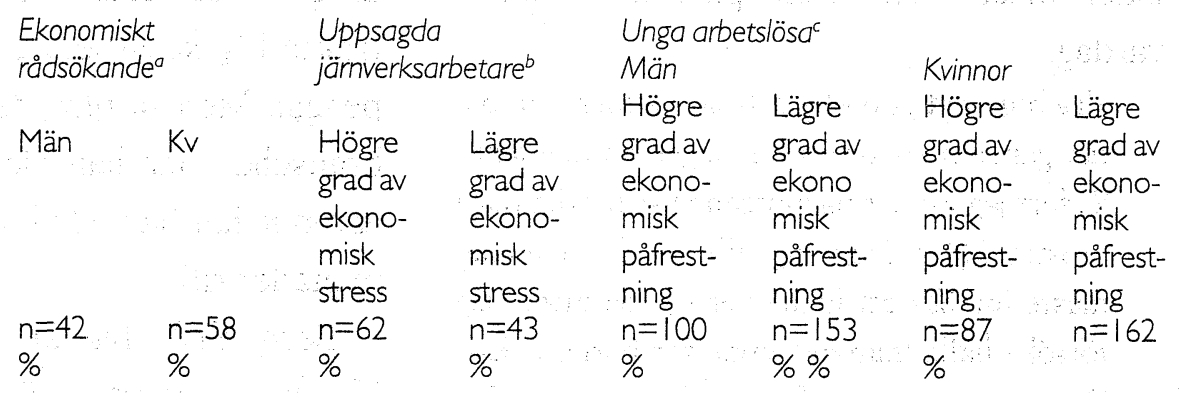

Hälsa/välbefinnande

Försämrat

allm. hälsotillstånd

Försämrat psykiskt

välbefinnande

Psykosomatiska

besvär

Allvarlig psyko-

somatisk

försämring

Levnadsvanor

Ökad kons. av

lugn. medel

Ökad alkohol-

konsumtion

Röker mer

Motionerar mindre

$\begin{array}{lll}76 & 75 & 45 \\ 76 & 79 & 50\end{array}$

$14 \quad 48$

$25 * * *$

47

$27 * *$

Sociala relationer

Minsk kont. med

släkt/vän

Minsk kont. med

grannar

Förs. stämn. i

familjen

Umgänge

Minskat umgänge

med föräldrar och

släktingar

Mera sällan till-

sammans med

kompisar

$16 \quad 56$

31 ***** 56

33 *****

Aktiviteter allmänt

Gör färre saker

på fritiden

54

57

13

0

34

9 ***

21

$11 *$

25

$25 \quad 3$

0

5

O**

$2 \quad 0$

23

$9 \quad 10$

$2 \quad 29$

\section{0}

9

7

33

$\begin{array}{ll}46 & 8 \\ 24 & 7\end{array}$

18

$10 \quad 23$

5

15

9.15

$\begin{array}{lllll}55 & 61 & 5 & 5 & 0\end{array}$

33

$\begin{array}{ll}25 & 2 \\ 69 & 42\end{array}$

9

Signifikansnivå $* * *=p<0.001, * *=p<0.01, *=p<0.05$

a) Starrin, Beckman, Hagquist \& Rantakeisu (1995).

b) Starrin \& Lundberg (1993).

c) Rantakeisu, Starrin \& Hagquist (1995b).

d) Med allvarliga psykosomatiska försämringar avses att man på frågorna om förändringar svarat att man besväras mycket oftare av endera magbesvär, huvudvärk eller sömnbesvär till följd av endera den svåra ekonomiska situationen (Ekonomiskt rådsökande), uppsägningen (Uppsagda järnverksarbetare) eller arbetslösheten (Unga arbetslösa).

Starrin, Rantakeisu \& Hagquist - Om arbetslöshetens ekonomi och skam 
att vara bättre om fem år. Det har gjort henne mycket ledsen. Vi kommer in $\mathrm{i}$ intervjun när hon svarar på en fråga om hur de ekonomiska bekymren påverkar hennes vardag.

"Jag blir väldigt orolig och så. Känner som om det går som en karusell i magen på mig jämt. Så fort jag vaknar på morgonen sitter det där i bröstet. Hjärtklappning, allt det där och man måste försöka att lugna ner sig. Så måste jag försöka hålla humöret uppe för barna också. De vet ju på ett ungefär hur det ligger till. De har ju haft det väldigt jobbigt också. Men man kan ju inte prata med dom om allt sånt - de förstår ju inte riktigt för att dom är ju så små. Det är så svårt att förklara för dom... Dom vill ha det och det och så säger jag att det har vi inte råd med just nu. Då kanske den äldste säger att det har ju min kompis. Det är kompistrycket... Jag försöker ändå att göra det bästa av situationen. De viktigaste är att de har kläder och mat... att jag finns hos dom... men det är jobbigt när räkningarna ligger på hög. När man börjar tro att man kommit $i$ kapp så kommer det nytt hela tiden. Man kommer ju aldrig i kapp. Det är den där ovissheten jämt som är så jobbig."

Intervjuaren: Tänker Du ofta på ekono$\min$ ?

Ewa: Ja det gör man ju. Det är det sista man tänker på innan man somnar och det första man tänker på när jag vaknar. Det är jobbigt. Jämt innan man somnar så tänker jag på det.

\section{Fallbeskrivning Erik och Berit}

Erik är i 40-års åldern. Han bor tillsammans med hustru och två barn i ett äldre litet hus. Erik möter upp på gårdsplanen. Den som intervjuar har haft lite svårt att hitta så det blir lite diskussion om just detta. Det är lätt att prata med Erik och intervjuaren bjuds in i det lilla vardagsrummet där Eriks fru Berit har dukat upp med nykokt kaffe och nybakade bullar. Vi sätter oss i en hörnsoffa. Erik är utbildad yrkesarbetare och har haft arbete fram tills för ett drygt ett år sedan. Han har varit en eftertraktad yrkesarbetare - tjänat bra med pengar. Men så blev det dåliga tider inom branschen och han blev uppsagd. För närvarande har han ALU-jobb som varar några månader till.

Berit, Eriks fru, är något yngre än Erik. Hon har varit arbetslös tidigare men är f.n. $i$ en utbildningsåtgärd. Hon är inte lika pratsam som Erik. Berit hoppas på att när hon är klar med utbildningen skall hon lättare att få ett jobb. Men samtidigt vet hon att det är svåra tider. För Berit är det viktigt att familjen håller ihop och att man tror på att det trots allt skall bli bättre. Berit förefaller göra allt för att hålla ihop familjen.

Eriks och Berits ekonomi går inte ihop. Situationen är pressad. För Erik och Berit finns ingen annan utväg än att »lägga en del räkningar under mattan. En del kan man betala andra kan man inter som Erik uttryckte det. Banken har varit ganska bra säger Erik. Det har varit kraftiga djupdykningar. Vi pratar om detta och Erik säger att man kan hamna efter på tre månader. Man kan rasa ganska kraftigt. Men sedan tar det mer än ett halvår att komma ikapp. Vi kommer in på hur allt detta påverkar Erik och Berits liv. Den fråga som ställs är hur den ekonomiskt svåra situationen påverkar vardagslivet. Erik tar till orda och säger att han »tänker på det här i stort sett dygnet runt från morgon till kvällı och fyller på:

„Ja mer än det hela natten. Jag har väldigt svårt att sova. Jag har t.o.m. mycket svårt att 
gå in i sovrummet och slappna av överhuvudtaget. Jag sitter uppe tills ögona trillar ihop av sig själv. Då går jag och lägger mig. Jag somnar av ren utmattning. Man tänker och tänker och tänker och ju mer man tänker desto värre blir det... Man får aldrig liksom ro i kroppen. Oron sitter i kroppen du kan aldrig lugna ner dig. Så fort man tänker på någonting som kostar pengar då är det kört och då är det lika bra att stiga upp för då kan man inte sova... Man tänker vad skall jag ta pengarna ifrån... När jag somnar sedan så sover jag oroligt - jag vaknar titt som tätt. När klockan ringer på morgonen är jag dödstrött. Det är ett jävla stressmoment. Man är väldigt uppskruvad hela tiden."

Erik berättar om en del mörka stunder. Hur det är när det är som svårast. Han säger:

"När det är som svårast tappar man intresset för allting. Man kanske håller på med någonting som man tycker är intressant. Snickrar, fixar någonting, och så börjar man tänka på räkningarna och den urusla ekonomin. Och då tänker man varför hảller jag pả med det här.. det tjänar ju ingenting till. Man kan inte se framåt... Allt känns meningslöst.ı

\section{Den skamliga aspekten}

För 20 år sedan publicerade två engelska forskare - Marsden och Duff - en undersökning av arbetslösa familjer. De skriver att av alla välfärdsstatens myter och skrönor har myterna om de arbetsskygga och snyltarna varit de sämst bestyrkta i fråga om bevismaterial; ändå har de visat sig vara de mest seglivade (Marsden \& Duff 1975). Dessa skrönor har ett gemensamt - de fritar samhällssystemet från kritik samtidigt som de tenderar lägga skulden på den enskilde arbetslöse.
I den allmänna debatten om arbetslöshetens orsaker förekommer anklagelser om att arbetslösa är arbetsovilliga och lata. Sådana anklagelser kan ha en stigmatiserande och skamgörande effekt och kan leda till att den enda acceptabla rollen för den arbetslöse är den som aktivt arbetssökande. Skamgörandet och stigmatiseringen får en mer tydlig effekt när den förankras i lagstiftning, institutioners praxis samt i de arbetslösas sociala nätverk. Det kan då leda till att arbetslösa isolerar sig från omgivningen. Denna isolering kan också ha att göra med att det förekommer negativa attityder bland arbetande mot arbetslösa som verkar stigmatiserande och bortstötande. Arbetslösa kan dessutom själva drabbas av fördomar och känslor av skuld och skam som gör att den enskildes arbetslöshet individualiseras vilket resulterar i att problemen kan vändas inåt och förvandlas till psykosomatiska besvär och liknande. Det innebär att de processer som försämrar den arbetslöses hälsa kan ha sin grund i en mindre socialt accepterad position (Olsén 1985). Hur andra betraktar den arbetslöse får således betydelse för hur den arbetslöse betraktar sig själv.

Det finns säkerligen många orsaker till myterna om arbetslösa som arbetsskygga och snyltare. Enligt Watson, som har intervjuat australiensiska ungdomar, finns det åtminstone två orsaker (Watson 1985). För det första är det en följd av den djupt rotade individualismen som nästan undantagslöst innebär att människor tenderar att förlägga orsakerna till sociala problem i första hand till individer och inte till strukturer. Det är den enskildes svaghet eller misslyckanden som blir orsaken till so- 


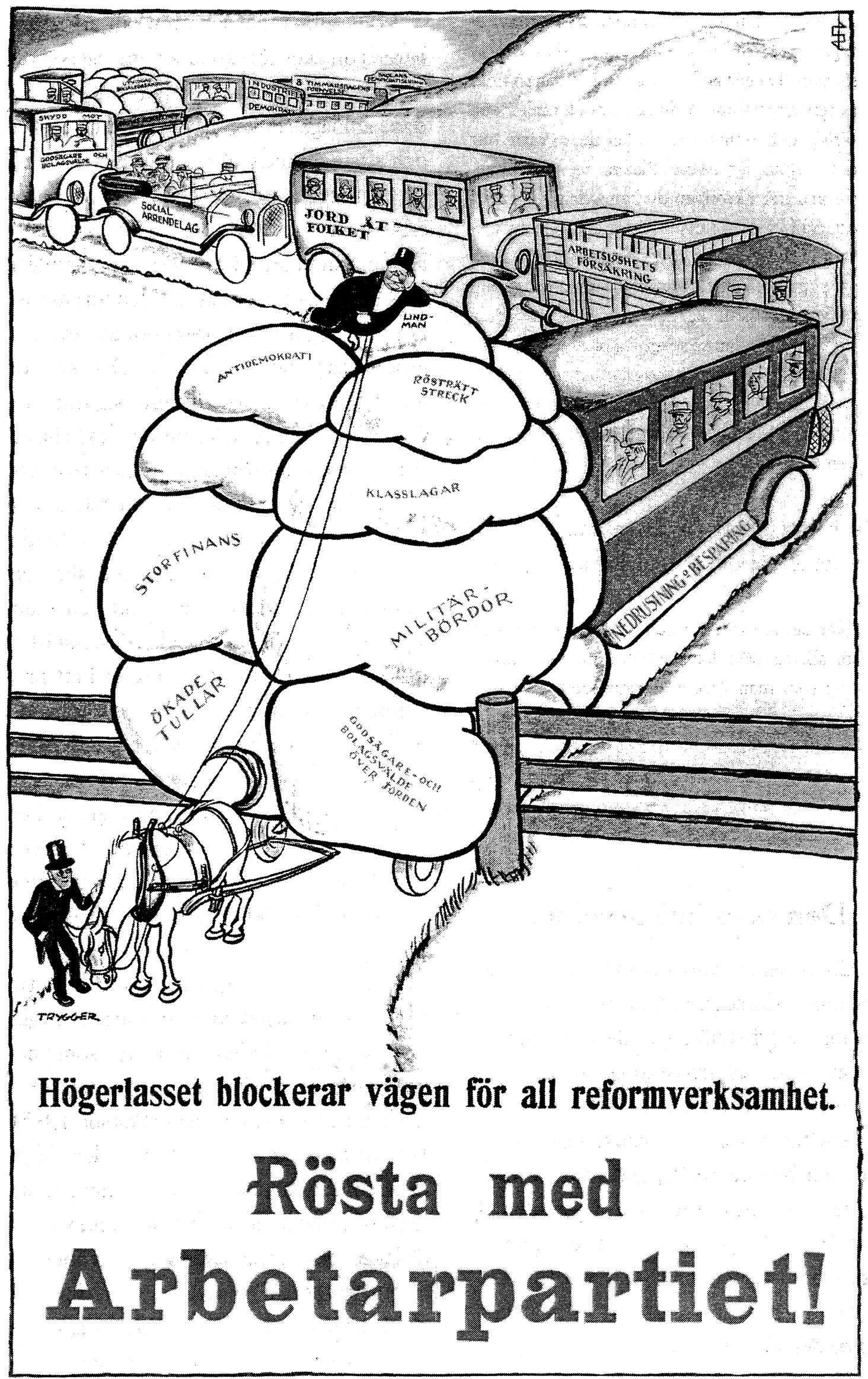

Socialvetenskaplig tidskrift nr 1-2 •96 
ciala problem. Massmedias, exempelvis kvällstidningarnas, fokusering på människor som utsatts för olika typer av påfrestningar, avvikare osv. är en sida av denna individualisering. För det andra är det en följd av arbetets roll och betydelse under kapitalismen. Arbete anses bara värdefullt då det utförs som lönearbete i produktion av varor eller tjänster, helst vinstgivande sådana. Aktiviteter som socialt sett är värdefulla men inte lönsamma i kapitalistisk mening räknas inte som »riktigt» arbete.

\section{Unga arbetslösa nedvärderas och nedvärderar sig själva}

Även om det finns antaganden om hur arbetslösa ungdomar betraktas av andra förefaller den empiriska forskningen kring detta vara relativt knapphändig. Det saknas - såvitt vi känner till - i mångt och mycket studier om uppfattningar om arbetslösa bland vänner, offentliga tjänstemän som möter de arbetslösa och den breda allmänheten (Kelvin \& Jarett 1985). I Breakwells engelska undersökning framgår att arbetslösa ungdomar, oavsett arbetslöshetstidens längd, ansåg att de som arbetade var överlägsna arbetslösa i en mängd olika avseenden (Breakwell 1986). De trodde vidare att wandra skulle vara mer kritiska mot arbetslösa än de själva och betydligt välvilligare inställda till de arbetande. I viss utsträckning hade de rätt. Skolungdomar mellan 15-18 år gavs samma frågor för att beskriva de två kategorierna. De var i högre utsträckning kritiska till de arbetslösa och positivare till de arbetande, även i jämförelse med de arbetslösas uppfattningar. Skolungdomarna var dock inte så kritiska respektive så välvilliga som de arbetslösa i undersökningen trodde att de skulle vara. Det verkar således som att arbetslösa har en överdrivet pessimistisk syn på hur andra betraktar dem. Av betydelse för den egna självbilden är emellertid hur man själv uppfattar att andra tänker om en själv. Enligt Willis är social stigmatisering en källa till separation mellan arbetslösa och icke-arbetslösa p.g.a. de förras rädsla för att de senare ska tänka att den arbetslöse inte vill arbeta (Willis 1986).

Frågan är emellertid inte enkel. En del menar att den stigma eller den skam som förknippas med arbetslöshet är ovanligare bland ungdomar än bland vuxna (Furnham 1985). Argumentet för detta är att ungdomsarbetslösheten är betydligt högre än vuxenarbetslösheten vilket skulle göra den mindre iögonfallande än vuxenarbetslösheten. Det skulle kunna tyda på att ungdomars arbetslöshet inte upplevs som lika skamlig som vuxnas. Dessutom antas arbetslösa ungdomar ha ett större socialt kontaktnät än arbetslösa vuxna. De skulle således ha större möjligheter att erhålla socialt stöd vilket mildrar upplevelser av stigma.

Skam kan ses som störningar i sociala band mellan människor och skamkänslor uppstår ur behovet av att känna samhörighet med andra (Retzinger 1991, Scheff 1990, 1992, 1994). Skam är förbundet med känslor av nedvärderande karaktär. Eales visar i sin studie att känslor av skam är vanligt förekommande bland vuxna arbetslösa män. Sådana känslor förekom hos var fjärde arbetslös (Eales 1989). I Eales studie var skam också förbundet med psykiska problem som t.ex. nedstämdhet och oro. Forskningen om relationen skam och ohälsa 
skulle kunna tyda på att upplevelser av skam kan ha en kraftfull och hittills ouppmärksammad betydelse för utveckling av hjärtsjukdom (Scheff 1992), depression (Hobilitzelle 1987), självmord (Shreve \& Kunkel 1991) och självmordsförsök (Arcel 1985).
Vilka erfarenheter har då arbetslösa ungdomar av nedvärderande attityder från sin omgivning? Finns det några skillnader med avseende på kön?

Av tabell 6 framgår att ungefär en femtedel av männen och 14 procent av kvinnorna har erfarenhet av att andra talat ned-

\section{Tabell 6}

Andelen unga arbetslösa, fördelat efter kön, som har erfarenheter av nedvärderande attityder under arbetslöshetssituation.

$\begin{array}{rr}\begin{array}{r}\text { Unga arbets- } \\ \text { lösa män }\end{array} & \begin{array}{r}\text { Unga arbets- } \\ \text { lösa kvinnor }\end{array} \\ \%\end{array}$

Andelen som under arbetslöshet...

...varit med om att andra varit irriterade på

Dig p.g.a. att Du går utan arbete

...varit med om att andra talat nedsättande om

Dig p.g.a att Du går utan arbete

...känt att andra betraktat Dig som mindre

kunnig p.g.a att du går utan arbete

känt att andra betraktat Dig som lat p.g.a

att Du går utan arbete

51

$42 *$

...varit med om att andra hăllit sig undan

Dig p.g.a. att Du går utan arbete

...känt att andra inte tagit notis av det Du

har sagt eller det Du har gjort, p.g.a

att Du går utan arbete

21

Signifikansnivå $* * *=p<0.001, * *=p<0.01, *=p<0.05$

Källa: Rantakeisu, Starrin \& Hagquist (1995a).

sättande om dem själva och i runda tal fem av tio män och fyra av tio kvinnor har upplevt att de blivit betraktade som lata. Andelen som har erfarenheter av att andra inte tagit notis av det de har sagt eller gjort för att de är $i$ avsaknad av arbete är 21 procent bland männen och 12 procent bland kvinnorna.

\section{Skam och ohälsa}

I tabell 7 redovisas sambandet mellan graden skamgörande inslag i miljön och förekomsten av olika typer av besvär.

Som framgår av tabell 7 förefaller faktorn skamgörande inslag i miljön i högre grad vara relaterad till allvarliga psykosomatiska besvär under arbetslöshet bland 


\section{Tabell 7}

Förekomsten av allvarliga psykosomatiska besvär, maktlöshet, nedstämdhet, nervositet eller oro bland kvinnor och män med olika erfarenheter av andras skamgörande.

\begin{tabular}{llll}
\multicolumn{2}{l}{ Skamgörande inslag i miljön } & \\
Unga arbetslösa män & \multicolumn{2}{l}{ Unga arbetslösa kvinnor } \\
Mer & Mindre & Mer & Mindre \\
$\%$ & $\%$ & $\%$ & $\%$ \\
$n=117$ & $n=136$ & $n=93$ & $n=156$
\end{tabular}

Allvarliga psykosomatiska

besvär ${ }^{b}$

Maktlöshet ${ }^{c}$

13

Nedstämdhet ${ }^{d}$

22

28

Nervositet eller oro ${ }^{e}$

30

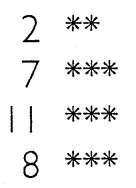

18

30

42

27

10

$11 * * * *$

$21 * * *$

17

Signifikansnivå $* * *=p<0.001$, $* *=p<0.01, *=p<0.05$

Källa: Rantakeisu, Starrin \& Hagquist (1995a).

a) Detta index har bildats utifrån följande items »H Har Du varit med om att människor varit irriterade på Dig på grund av att Du går utan arbete?«,») Har Du varit med om att andra talat nedsättande om Dig på grund av att Du går utan arbete?«,» Har Du upplevt att andra hållit sig undan Dig på grund av att Du går utan arbete?«,» Har Du känt att andra betraktat Dig som mindre kunnig på grund av att Du går utan arbete?«,»H Har Du känt att andra betraktat Dig som lat p.g.a att Du går utan arbete?«,»H Har Du känt att andra inte tagit notis av det Du har sagt eller det Du har gjort på grund av att Du går utan arbete?«. Om man svarat med alternativen »)a många gånger «,ja några gånger«,»)a någon enstaka gång« på minst två av dessa items har detta kategoriseras som »mer av skamgörande inslag i miljön«. Om man svarat en eller ingen gång med någon av dessa svarsalternativ har detta kategoriserats som »mindre av skamgörande inslag i miljön«. Se Rantakeisu, Starrin \& Hagquist (1995a).

b) med allvarliga psykosomatiska besvär avses att man i stort sett dagligen besväras av endera magont/magbesvär,huvudvärk eller sömnbesvär.

c) besväras i stort sett dagligen eller några gånger i veckan av maktlöshet

d) besväras i stort sett dagligen eller några gånger i veckan av nedstämdhet

e) besväras i stort sett dagligen eller några gånger i veckan av nervositet eller oro

män än bland kvinnor även om utbredningen av allvarliga psykosomatiska besvär är störst bland gruppen kvinnor som lever i en mer skamgörande miljö. När det gäller maktlöshet och nedstämdhet är dessa besvär mest utbredda bland kvinnor som lever i en miljö som kan karaktäriseras som högre grad av skamgörande. För båda könen gäller att utbredningen av maktlöshet, nedstämdhet, nervositet eller oro är betydligt större bland dem som lever i en mer skamgörande miljö.

I tabell 8 redovisas försämringar i hälsan hos arbetslösa unga män och kvinnors efter det att de blivit arbetslösa.

Allvarliga psykosomatiska försämringar, försämrad hälsa och försämrat psykiskt välbefinnande förekommer främst bland män och kvinnor som lever i en mer skamgörande miljö. T.ex. är allvarliga psykosomatiska försämringar mer än dubbelt så vanligt bland dem som lever i en sådan miljö jämfört med dem som har inte lever i en sådan.

Ökad alkoholkonsumtion bland män förekommer i nästan tre gånger så stor ut- 


\section{Tabell 8}

Förändringar i hälsan hos arbetslösa unga män och kvinnor med olika erfarenheter av andras skamgörande.

\begin{tabular}{llll}
\multicolumn{2}{l}{ Skamgörande inslag i miljön } & \\
Unga arbetslösa män & Unga arbetslösa kvinnor \\
Mer & Mindre & Mer & Mindre \\
$\%$ & $\%$ & $\%$ & $\%$ \\
$n=117$ & $n=136$ & $n=93$ & $n=156$
\end{tabular}

Allvarliga psykosomatiska

försämringara

27

43

Försämrad allmän hälsa ${ }^{b}$

Försämrad psykisk hälsac

Levnadsvanor

Ökad kons. av lugn medel

Ökad alkoholkonsumtion

Rökermer

Motionerar mindre

Umgänge

Minskat umgänge med

föräldrar och släktingar

Mera sällan tillsammans

med kompisar

Aktiviteter allmänt

Gör färre saker på fritiden
55

4
36
18
18

11

15

33
11 **

$26 *$

$28 * * *$

1

$13 * * * *$

$9 *$

$5 * *$

5

$7 *$

12

2 ****

28

23

43

56

$10 * *$

$28 *$

33 **

1

7

$12 *$

$16 \quad 10$

Signifikansnivå $* * *=p<0.001, * *=p<0.01, *=p<0.05$

Källa: Rantakeisu, Starrin \& Hagquist (1995a).

a) Med allvarliga psykosomatiska försämringar avses att man erfarit att någon av besvären huvudvärk, sömnbesvär eller magbesvär/magont uppträder mycket oftare efter det att man blivit arbetslösa.

b) Mycket sämre eller något sämre hälsa till följd av arbetslösheten

c) Mycket sämre eller något sämre psykisk hälsa till följd av arbetslösheten

sträckning bland dem som lever i en mer skamgörande miljö. Aktivitetsnivån tycks också minska framförallt hos den grupp som lever i en sådan miljö.

\section{Ekonomisk påfrestning och påförande av skam}

Det är känt att arbetslösa kan uppleva att de är "stämplade»,t. ex. att de blir nedvärderade av omgivningen. Detta är sanno- likt mer tydligt under perioder med låg arbetslöshet än under hög arbetslöshet. Det är sannolikt betydligt mindre stigmatiserande och skamligt att vara arbetslös om också 300.000 andra svenskar är det än om enbart 1.000 andra svenskar är arbetslösa. För arbetslöshet betraktat ur ett ekonomiskt stressperspektiv torde det motsatta förhållandet råda. Ju högre arbetslösheten är desto svårare blir det sannolikt för den 
arbetslöse att klara sin försörjning, p.g.a. att sociala skyddsnät tenderar att försämras när arbetslösheten är stor i samhället.

\section{Ekonomi-skam modellen}

Det finns skäl att anta att de sociala och hälsomässiga problem som uppstår till följd av arbetslöshet har att göra med en kombination av ekonomisk påfrestning och skamgörande. Mer precist borde man mot bakgrund av det resonemang som förts förvänta sig en anhopning av besvären i den grupp som dels är utsatta för högre grad av ekonomisk påfrestning och dessutom lever i en mer skamgörande social miljö. I tabell 9 redovisas data från undersökningen om unga mäns och unga kvinnors arbetslöshet (Rantakeisu, Starrin \& Hagquist 1995b).

Som framgår av tabell 9 har ekonomiskam modellen något större förmåga att redogöra för variationerna i olika typer av besvär hos unga arbetslösa män än hos unga arbetslösa kvinnor. För unga arbetslösa män är utbredningen av allvarliga psykosomatiska besvär i hög grad koncentrerad till dem som lever under både hög grad av ekonomisk påfrestning och en mer skamgörande miljö. Allvarliga psykosomatiska besvär och maktlöshet förekommer knappt hos den grupp unga män som lever under mindre grad av ekonomisk påfrestning och som lever $i$ en mindre skamgörande social omgivning. För kvinnor är besvären allmänt sett mer fördelade - även om vi kan se en klar överrepresentation bland den grupp som likt de unga männen lever under högre grad av ekonomisk påfrestning samtidigt som de lever i en mer skamgörande miljö.

Tabell 9 visar även att klara hälso- försämringar främst är lokaliserade till den grupp män och kvinnor som är »exponerade« för högre grad av ekonomisk påfrestning och lever i en omgivning som är mer skamgörande. T.ex. är självrapporterad allvarlig psykosomatisk försämring bland unga arbetslösa män till följd av arbetslöshet mer än sju gånger vanligare bland unga män som är utsatta för dels en högre grad av ekonomisk påfrestning och dels för en mer skamgörande miljö jämfört med unga arbetslösa män som inte är utsatta för något av detta.

Även vissa hälsorelaterade beteenden förefaller förändras framförallt hos dem som är utsatta för högre grad av ekonomisk påfrestning och en mer skamgörande social omgivning. Detta gäller i högre grad för unga arbetslösa män och i mindre utsträckning för unga arbetslösa kvinnor.

Av tabell 9 framgår vidare att förändringar i umgänges- och aktivitetsvanor är främst lokaliserad till den grupp unga arbetslösa män och kvinnor som är föremål för hög grad av ekonomisk påfrestning samtidigt som de lever i en mer skamgörande miljö.

\section{Sammanfattning och ett försök till utvikning}

Vårt syfte med föreliggande artikel har varit att undersöka om två aspekter av arbetslöshet - den ekonomiska aspekten och den skamliga aspekten - kan bidra till en ökad förståelse av arbetslöshetens konsekvenser. Vi tycker oss finna stöd för antagandet att ju allvarligare den ekonomiska påfrestningen är under arbetslöshet, desto större är risken att drabbas av ohälsa och sociala problem. Vi tycker oss också finna 


\section{Tabell 9}

Hälsostatus, hälsoförändringar, förändringar i hälsorelaterade beteenden samt med avseende på grad av ekonomisk påfrestning och erfarenheter av andras skamgörande, fördelat på kön.

$\begin{array}{lllll}\text { Högre grad } & \text { Högre grad } & \text { Lägre grad } & \text { Lägre grad } & \text { Signi- } \\ \text { av ekonomisk } & \text { av ekonomisk } & \text { av ekonomisk } & \text { av ekonomisk } & \text { fikans- } \\ \text { påfrestn. och } & \text { påfrestn. och } & \text { påfrestning } & \text { påfrestning } & \text { nivå } \\ \text { en mer skamg. } & \text { en mindre } & \text { och en mer } & \text { och en mindre } & \\ \text { miljö } & \text { skamg. miljö } & \text { skamg. miljö } & \text { skamg. miljö } \\ (\text { män } n=56 & (\text { män } n=44 & (m a ̈ n n=61 & (\text { män } n=92 \\ \text { kvn=45) } & k \vee n=42) & k \vee n=48) & k \vee n=114) \\ \% & \% & \% & \%\end{array}$

Hälsostatus

Allvarliga psyko-

somatiska besvär $r^{a}$

män

19

kv

26

2

Maktlöshet

män

28

kv

51

13

19

Nedstämdhet

män

36
54

15

kV

16

Nervositet/oro

män.

38

kv

31

22

14

26

8

2

9

$\begin{array}{lr}16 & 1 \\ 11 & 10\end{array}$

22

8

31

20

22

4

15

Hälsoförändringar

Allvarliga psykoso-

matiska försämringare

män

Försämrad allmän

hälsa

män

kv

58

\section{1}

33

19

Försämrat psykiskt

36

31

26

välbefinnandes

män

63

kv

71

47

39

48

19

28

Förändringari hälso-

relaterade beteenden

Ökad konsumtion av

lugnande medel

män

kv

8

Ökad konsumtion av alkohol

män

kv

Ökad rökkonsumtion

män

kv

Minskad motion

män

kv 


$\begin{array}{lllll}\text { Högre grad } & \text { Högre grad } & \text { Lägre grad } & \text { Lägre grad } & \text { Signi- } \\ \text { av ekonomisk } & \text { av ekonomisk } & \text { av ekonomisk } & \text { av ekonomisk } & \text { fikans- } \\ \text { påfrestn. och } & \text { påfrestn. och } & \text { påfrestning } & \text { påfrestning } & \text { nivå } \\ \text { en mer skamg. } & \text { en mindre } & \text { och en mer } & \text { och en mindre } \\ \text { miljö } & \text { skamg. miljö } & \text { skamg. miljö } & \text { skamg. miljö } \\ (\text { män } n=56 & \text { (män } n=44 & \text { (män } n=61 & \text { (män } n=92 \\ \text { kv } n=45) & \text { kv } n=42) & \text { kv } n=48) & \text { kv } n=114) \\ \% & \% & \% & \%\end{array}$

Förändringar

sociala relationer

Minskat umgänge

med föräldrar och

släktingar

män

15

kv

7

Minskat umgänge

med kompisar

män

20

kv

20

5

13

7

4

3

7

4

Förändringar fritid

Gör färre saker på

fritiden

män

38

kv

29

18

12

28

27

10

8

4

Signifikansnivå $* * *=p<0.001, * *=p<0.01, *=p<0.1$

Källa: Rantakeisu, Starrin \& Hagquist (1995b).

a) Med allvarliga psykosomatiska försämringar avses att man erfarit att någon av besvären huvudvärk, sömnbesvär eller magbesvär/magont uppträder mycket oftare efter det att man blivit arbetslösa.

b) besväras i stort sett dagligen eller några gånger i veckan av maktlöshet

c) besväras i stort sett dagligen eller några gånger i veckan av nedstämdhet

d) besväras i stort sett dagligen eller några gånger i veckan av nervositet eller oro

e) Med allvarliga psykosomatiska försämringar avses att man erfarit att någon av besvären huvudvärk, sömnbesvär eller magbesvär/magont uppträder mycket oftare efter det att man blivit arbetslösa.

f) Mycket sämre eller något sämre hälsa till följd av arbetslösheten

g) Mycket sämre eller något sämre psykisk hälsa till följd av arbetslösheten

stöd för att ju mer av skamgörande inslag det finns i den arbetslöses sociala omgivning desto allvarligare blir de sociala och hälsomässiga konsekvenserna av arbetslöshet. Slutligen har vi kombinerat antagandet om ekonomisk påfrestning med antagandet om skamgörande. Vi har funnit att nekonomi-skam" har ett relativt gott empiriskt stöd och främst då bland unga män. Ekonomi-skam modellen - som vi har behandlat den - postulerar att det är kombinationen av nekonomisk påfrestning" och "skam- görande« som förklarar en stor del av variationerna i ohälsa och sociala problem under arbetslöshet. Förhoppningsvis kan fortsatt forskning kasta mer ljus över detta fenomen.

Ekonomi-skam modellen kan vi betrakta som ett specialfall av en mer generell modell som vi skulle viljä benämna $e k o$ nomi-sociala band modellen (Rantakeisu, Starrin \& Hagquist 1995b). I modellen ingår faktorn sociala band som fäster uppmärksamheten på sociala relationer (se fi-

Starrin, Rantakeisu \& Hagquist - Om arbetslöshetens ekonomi och skam 
gur 1). Skam och stolthet kan ses som de mest primära sociala emotionera eftersom de båda på olika sätt är ett uttryck för sociala band (Scheff 1990). Skam uttrycker ansträngda relationer (avbrutna eller hotade) medan stolthet uttrycker avspända och välfungerande relationer. Ekonomi-sociala band-modellen skulle således inkludera såväl skam som stolthet och därmed kunna ha ett mer generellt värde för att förklara och förstå sociala och hälsomässiga problem En hypotes som kan formuleras utifrån ekonomi-sociala bandmodellen är att kombinationen "mindre ekonomiska resurser" och "mer skamfyllda sociala band" ökar risken för "ohälsa» och försämrat välbefinnande. En annan hypotes som kan formuleras är att kombinationen "mer ekonomiska resurser" och »sociala band som är mer präglade av stolthet" ökar chansen för välbefinnande och god hälsa.

\section{Figur 1}

Ekonomi-sociala band

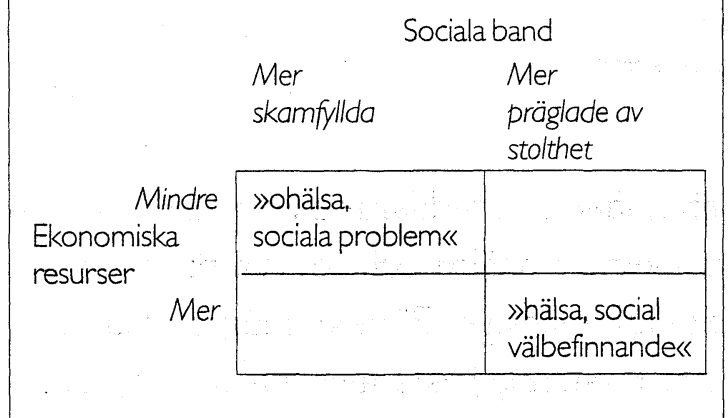

Ekonomi-sociala band modellen har beröringspunkter med den numera väl etablerade kontroll-krav-teorin (control-demand) (Karasek \& Theorell 1990). Kontrollaspekten i Karasek och Theorells teori har enligt vårt sätt att se det en klar anknyt- ning till ekonomiska förhållanden eftersom en god privatekonomi ökar möjligheterna till påverkan och egenkontroll. Men kontrollbegreppet i deras modell är även relaterat till den sociala organiseringen av arbete. Konkret handlar då kontrollbegreppet om de möjligheter som står till buds för att påverka olika aspekter av arbetet som t.ex. planering, genomförande och utvärdering. Den ekonomiska aspekten täcker bara delvis detta och gör det i den självklara meningen att en mycket god ekonomi gör det lättare för en enskild individ att fatta ett beslut om att säga upp sig om andra försök att öka kontrollutrymmet i arbetet har misslyckats.

Det är mycket troligt att det som betraktats som arbetsrelaterad stress till betydande delar har att göra med ekonomisk stress. En studie visar att den rapporterade upplevda stressen $i$ arbetslivet när allt kom omkring skulle kunna reduceras till hälften om man kontrollerar graden av ekonomiska svårigheter (Pearlin \& Liberman 1979).

Den andra delen i Karasek \& Theorells modell - krav (demand) - innefattar små eller stora eller rent av för små eller för stora förväntningar från omgivningen. Dessa förväntningar indikerar i vår modell kvalitén hos de sociala banden som kan vara mer skamfyllda eller som kan vara mer präglade av stolthet.

Källorna till den stress som forskare idag har uppmärksammat genom begreppen demand-control skulle således - om våra antaganden är giltiga - till betydande delar kunna inrymmas i den modell som vi benämner ekonomi-sociala band-modellen.

Den modell som vi här har formulerat - 
och som vi benämner ekonomi-sociala band modellen - kan kanske visa sig ha ett visst värde för att förstå och förklara bl.a. sociala och hälsomässiga förhållanden.
Men modellen är ännu oprövad. Därför behövs såväl fortsatt empirisk forskning som teoretiskt utvecklingsarbete.

\section{Referenser}

Adler Karlsson G(1990) Lärobok för 90-talet. Om vår överlevnads villkor. Prisma.

Allatt P \& Yeandle S (1992) Youth Unemployment and the Family, Voices of Disordered Times. London: Routledge.

Ambjörnsson R (1988) Den skötsamme arbetaren. Stockholm: Carlssons bokförlag.

Arcel L T (1985) "Skam og selvmordsforsog hos en pubertetspige." Psyke \& Logos, 6, 25-58.

Breakwell G M (1985) »Young people in and out of work.» i Roberts, B., Finnegan, R. \& Gallie, D., red,:

New Approaches to Economic life - Economic restructuring: unemployment and the social division of labour. Manchester University Press.

Brenner H (1983) "Mortality and Economic Instability. Detailed Analyses for Britain and Comparative Analyses for Selected Industrialized Countries." International Journal of Health Services, 13, 563620.

Brenner H (1971) "Economic changes and heart disease mortality." American Journal of Public Health, 61:3, 606-611.

Brenner H (1987) „Economic instability, unemployment rates, Behavioural risks and mortality rates in Scotland 1952-1983. International Journal of Health Services, 17:3, 475-487.

Brenner H (1979) "Mortality and the National Economy: A Review and the experiences of England and Wales, 1936-1976." The Lancet, 15, 568-573.

Campbell A (1981) The Sense of Well-being in America: Recent Patterns and Trends. New York: McGraw-Hill.

Carle J (1992) Ungdomsarbetslöshet, välfärd och livsstil. Göteborgs universitet: Sociologiska institutionen.

Durkheim E(1968) Självmordet. Uppsala: Argos.

Eales M J (1989) "Shame among unemployed men."Social Science and Medicine, 28:8, 783-789.

Furnham A (1985) »The determinants of attitudes towards social security recipients." British Journal of Social Psychology, 24, 19-27.

Hagquist C \& Starrin B (1994) "Barns hälsa och föräldrars arbetslöshet." Socialvetenskaplig tidskrift, 4, 287-301.

Hagquist C, Carlsson K, Rantakeisu U \& Starrin B (1996) Ung och arbetslös. Karlstad: Centrum för folkhälsoforskning (under arbete).

Hagquist C, Starrin B \& Carlsson K (1993) Unga arbetslösa och ungdomspraktikanter. Karlstad: Centrum för folkhälsoforskning, Research Reports No 3.

Helldén A (1994) Social Arrogans. Stockholm: Carlssons bokförlag.

Hobilitzelle W (1987).»Differentiating and Measuring Shame and Guilt: The Relation between Shame and Depression. « i Lewis, H. B., red,: The Role of Shame in Symptom formation. New Jersey: Lawrence Erlbaum Ass.

Karasek R \& Theorell T (1990) Healthy Work - Stress, Productivity and the Reconstruction of Working Life. New York: Basic Books.

Starrin, Rantakeisu \& Hagquist - Om arbetslöshetens ekonomi och skam 
Kelvin P \& Jarrett J E (1985) Unemployment - It's social psychological effects. Cambridge University Press.

Link B \& Dohrenwend B P (1980) „Formulations of hypotheses about the true prevalence of demoralization in the United States." i Dohrenwend, B. P., Dohrenwend, B. S., Gould, M. S., Link, B., Neugebauer, R. \& Wunsch-Hitzig, R., red,: Mental Illness in the United States: Epidemiological Estimates. New York: Praeger.

Marsden D \& Duff E (1975) Workless. Harmondsworth: Penguin.

McKeown T (1975) The Role of Medicine: Dream Mirage or Nemesis. Princeton.

Mohr G \&Frese M(1978) "Arbeitslosigkeit und Depression. « i Wacker, A., red,: Vom Scock zum Fatalismus? Frankfurt: Surkamp.

Olsén P (1985), Arbetslöshetens socialpsykologi. Stockholm: Natur och Kultur

Pearlin L I \& Lieberman M A (1979) "Social sources of emotional distress. " i Simmons, R G., red,: Research in Community and Mental Health. Greenwich: JAI Press.

Rantakeisu U, Starrin B \& Hagquist, C (1995a) „Unemployment, shaming and ill-health." Karlstad: Centrum för folkhälsoforskning.

Rantakeisu U, Starrin B \& Hagquist, C (1995b) »Economic hardship and shaming during unemployment.«Karlstad. Centrum för folkhälsoforskning.

Retzinger S M (1991) Violent emotions. Shame and Rage in Marital Quarrels. London: Sage Publications.

Rosvold E O \& Hammer T (1991) "Psykisk helse och arbeidsledighet - En longitudinell undersokelse av unge arbiedsledige i Norge." Tidskrift for samfunnsforskning, 32, 121-142.

Scheff T J (1994) Bloody Revenge, Nationalism and War. Oxford: Westview Press.

Scheff T J (1992) „Emotion and Illness: Anger, bypassed shame and heart disease." Perspectives on Social Problems, 3, 117-134.

Scheff T J (1990) Microsociology. Discourse, Emotion, and Social Structure. Chicago: The University Chicago Press.

Shreve B \& Kunkel M A (1991) "Self-Psychology, Shame, and Adolescent Suicide: Theoretical and Practical Considerations." Journal of Councelling \& Development, 69, 305-311.

Starrin B \& Svensson P-G(1992) Hälsans ojämlika förutsättningar- Om social klass, fattigdom och ohälsa. Karlstad: Centrum för folkhälsoforskning, Research Reports No 1.

Starrin B \& Lundberg B (1993) „Uppsagd från järnverket - En studie av ekonomisk stress och ohälsa.»Socialmedicinsk tidskrift, 5, 221-227.

Starrin B, Beckman A, Hagquist C \& Rantakeisu U (1995) Tyngda av skulder-Omatt leva under ekonomisk stress. Karlstad: Centrum för folkhälsoforskning, Research Reports No 2.

Underlid K (1992) Arbeidslaus. Oslo: Det Norske Samlaget.

Viinamäki H, Koskela K, Niskanen L \& Arnkill R (1993) „Unemployment, Financial Stress and Mental Well-Being: A Factory Closure Study.» Eur. J. Psychiat., 7:2, 95-102.

Warr P, Banks M \& Ullah P (1985) „The experience of unemployment among black and white urban teenagers." British Journal of Psychology, 76, 75-97.

Watson I (1985) Double Depression. Schooling, Unemployment and Family life in the Eighties. Sydney: George Allen \& Unwin.

Williams D R (1990) "Socioeconomic Differentials in Health: A Review and Redirection." Social Psychology Quarterly, 53:2, 81-99.

Willis P (1986) „Unemployment: the final inequality." British Journal of Sociology and Education, 7:2, 155-169. 


\section{Summary}

\section{Finances and shame during unemployment}

The reason why unemployment can have negative social and health-related consequences is a question that has interested researchers and public debaters for a couple of decades. In the article a model is formulated the "finances-shame model" - in order to increase the understanding of the social and health-related consequences of unemployment. The "finances-shame model" is made up of two aspects of work/unemployment: a financial aspect which concerns maintenance and a specific social aspect which concerns morals, i.e. the possibly shameful part of unemployment.

The results of the study indicate that the "finances-shame model" is somewhat more capable of accounting for the variations in different types of disorders among young unemployed men than among young unemployed women. The spread of serious psychosomatic disorders among young unemployed men is very much concentrated on those who live under a major degree of financial strain as well as in a more shaming environment. Serious psychosomatic disorders and powerlessness hardly exist among the group of young men who live under a minor degree of financial strain and in a less shaming environment. Among women, the disorders are generally more spread even if the group of women who, like the young men, live under a major degree of financial strain and, at the same time, in a more shaming environment is clearly overrepresented.

The results also show that obvious health deteriorations are mainly localized in the group of men and women who are exposed to a major degree of financial strain and live in a more shaming environment. Furthermore, the study indicates that changes in habits regarding social intercourse and activities are mainly localized in the group of young unemployed men and women who are subject to a major degree of financial strain at the same time as they live in a more shaming environment.

The "finances-shame model" can be regarded as a special case of a more general model, which we call the "finances-social bonds modelu. Shame and pride can be seen as the most primary social emotions, as both give expression to social bonds in different ways. Shame expresses strained relations (interrupted or threatened), while pride expresses relaxed and very good relations. Accordingly, the "finances-social bonds model" includes both shame and pride and could therefore have a more general value in explaining and understanding social and health-related problems from a general point of view. One hypothesis formed from the "finances-social bonds model" is that the combination of "fewer financial resources" and "more social bonds filled with shame" increases the risk of "ill-health" and deteriorated well-being. Another hypothesis that can be formed is that the combination of "more financial resources" and "social bonds more characterized by pride» increases the chance of well-being and good health. 